\title{
Acidification of the gill cells of the shore crab Carcinus mediterraneus: its physiological significance
}

\author{
Č. Lucu $^{1} \&$ D. Siebers ${ }^{2}$ \\ ${ }^{1}$ Center for Marine Research Rovinj, Institute Ruder Boškovic; 52210 Rovinj, Croatia \\ ${ }^{2}$ Biologische Anstalt Helgoland; Notkestr. 31, D-22 607 Hamburg, Germany
}

\begin{abstract}
In a preparation of isolated gills of the shore crab Carcinus mediterraneus perfused with dilute sea water $\left(\mathrm{pH} 8.1,200 \mathrm{mM} \mathrm{Na}^{+}\right)$which was identical to the bathing solution of the gill, acidification of the collected perfusate was observed. Acidification was not affected by $10^{-4} \mathrm{M}$ EIPA (5-[N-ethyl-N-isopropyl]amiloride), a strong inhibitor of $\mathrm{Na}^{+} / \mathrm{H}^{+}$exchange. However, in the presence of $10^{-4} \mathrm{M}$ acetazolamide, acidification was greatly blocked. The significant decrease of the acid load of the perfusate is considered to be a result of inhibition of the branchial intracellular carbonic anhydrase catalyzing the formation of $\mathrm{H}^{+}$ions.
\end{abstract}

\section{INTRODUCTION}

Acid-base balance is a complex regulatory phenomenon involving the interaction of a number of physiological and biochemical processes such as respiratory gas exchange, ion transport and the intermediary metabolism of the cells. The gill cells as a selective interface between the environment and the internal milieu of a broad group of aquatic organisms plays, besides other functions, a crucial role in acid-base regulation.

In spite of the interest in studies of the $\mathrm{Na}^{+} / \mathrm{H}^{+}$exchanger in crustacean gills, the role of hydrogen in acid-base regulation has not been studied specifically. The presence of an electrogenic amiloride-sensitive $2 \mathrm{Na}^{+} / \mathrm{H}^{+}$exchanger was experimentally discovered in isolated membrane vesicles of Carcinus gills by Shetlar \& Towle (1989) and in the freshwater crustacean hepatopancreas by Ahearn \& Clay (1989). It could not, however, be directly related to physiological functions.

In isolated perfused crab gills a significant reduction in $\mathrm{Na}^{+}$influx by amiloride was observed in Carcinus $\left(\mathrm{K}_{\mathrm{i}}=7 \cdot 10^{-5} \mathrm{M}\right.$ ) (Lucu \& Siebers, 1986), and in the crab Callinectes sapidus $\mathrm{Na}^{+}$influx was reduced by $39 \%$ of the control values (Burnett \& Towle, 1990). The amiloride effect was considered to be a result of the blockage of the $\mathrm{Na}^{+} / \mathrm{H}^{+}$ antiporter, but direct evidence of this effect on $\mathrm{H}^{+}$secretion has never been experimentally verified.

The sodium-independent $\mathrm{pH}$ recovery from an intracellular load which was probably inhibited by cellular ATP depletion, suggests the presence of an apically located ATPdriven $\mathrm{H}^{+}$pump, a possibility which has been suggested for branchial cells of the fiddler crab Uca tangeri but never been experimentally verified (Krippeit-Drews, 1989). The presence of an electrogenic proton pump in trout gill epithelium was suggested by Lin \& Randall (1991). 
The purpose of this study was to test the physiological role of the extracellular acidification of the perfusate after passing along the basolateral surfaces of the gill lamellae of the isolated perfused Carcinus gill epithelium.

\section{MATERIALS AND METHODS}

Adult crabs Carcinus mediterraneus were collected on the Istrian coast of the Adriatic Sea. The crabs were acclimated to laboratory conditions $\left(20^{\circ} \mathrm{C}\right.$, salinity $20 \mathrm{ppt}$.) for at least 14 days in static renewal aquarium systems. The posterior gills (Nos 7 and 8) were then excised, and the isolated gill preparation was perfused by a peristaltic pump from the afferent to the efferent hemolymph vessels as described by Lucu \& Siebers (1986). Gills were perfused with dilute sea water ( $\mathrm{DSW} ; \mathrm{pH}=8.12 \pm 0.07$ ) which was identical to the solution in which the gills were immersed. The DSW stock was filtered using Millipore filters $(0.45 \mu \mathrm{m}$ mesh diameter) and used throughout the experiments. The $\mathrm{pH}$ of the DSW was measured with Ingold electrodes in combination with a Knick digital $\mathrm{pH}$ meter immediately before and after passing the gills. For determination of the standard $\mathrm{pH}$ curve, $25 \mathrm{ml} \mathrm{DSW}$ were titrated with $0.01 \mathrm{M} \mathrm{HCl}$ (Titrisol, Merck) solution. Net acidification of the perfusate was expressed as $\mathrm{nmol} \mathrm{H}^{+} \cdot \mathrm{mg}^{-1}$ gill fresh weight $\cdot \mathrm{h}^{-1}$. Acetazolamide was purchased from Sigma (München), and the amiloride derivative EIPA was a kind gift from Hoechst (Frankfurt).

\section{RESULTS AND DISCUSSION}

Extracellular acidification was measured in the isolated crab gill epithelium perfused with dilute sea water identical to the bathing medium (Fig.1). The acid load of the perfusate remained in a steady state during the 2 hours of the experimental procedure (Fig. 1). Two hours after excision of the gills, the viability of the tissue measured by means

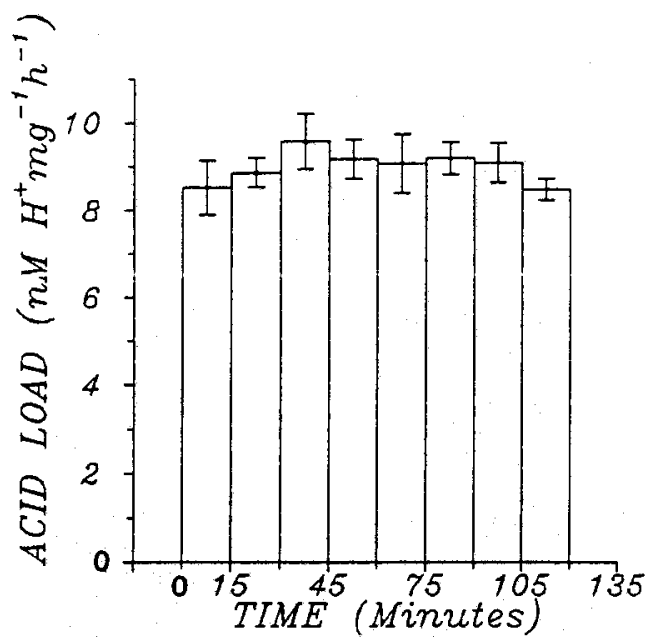

Fig. 1. Carcinus mediterraneus. Acid load of the dilute sea water (DSW) after perfusion of the isolated posterior gill with identical solution in the bath. Data are means \pm s.d. of 6 experiments 
of Trypan blue exclusion was over $85 \%$. Therefore, gills were considered as suitable organs for further studies of the effects of specific inhibitors on the acid load.

Apparent proton excretion from the isolated perfused Carcinus gills was not inhibited by EIPA (5-[N-ethyl- $\mathrm{N}$-isopropyl] amiloride), the most potent amiloride derivative for inhibition of $\mathrm{Na}^{+} / \mathrm{H}^{+}$exchange (Kleyman \& Cragoe, 1988) (Fig. 2a). Previously described microspectrofluorimetric studies have shown that intracellular acidification is not an amiloride-sensitive process (Lucu, 1993). The results presented in this work, in addition to those on amiloride referred to by Lucu (1993), show that there is no indication of the presence of basolaterally-located amiloride-sensitive $\mathrm{Na}^{+} / \mathrm{H}^{+}$exchangers in $\mathrm{crab}$ gills.

In the presence of acetazolamide $\left(10^{-4} \mathrm{M}\right)$ on the apical and the basolateral side acidification of the perfusate was reduced by about $60 \%$ of control values (Fig. 2b). This finding suggests that the facilitating effect of the branchial enzyme carbonic anhydrase on the interconversion of $\mathrm{CO}_{2}$ and $\mathrm{H}^{+}$plays a role in the regulation of the hemolymph acid-base balance. It has been suggested by Henry (1987) that a portion of CA of the crustacean gills is localized on the basolateral membrane side.

In all living cells, acidification depends only on the concentration of proton donors and proton acceptors and on the strength with which they bind protons. Exchange of acid-base equivalents between the intracellular and the extracellular space is the primary mechanism by which extracellular $\mathrm{pH}$ is regulated (Wheatly \& Henry, 1992).

A continuous supply of $\mathrm{H}^{+}$ions may be used for removal of $\mathrm{NH}_{3}$ from the cells, thus facilitating ammonia excretion as described for the fish gills by Wright et al. (1989). The gills of ammonotelic aquatic organisms are the dominant organs of nitrogen excretion. Ammonia is one of the excretory products of nitrogen metabolism produced by the
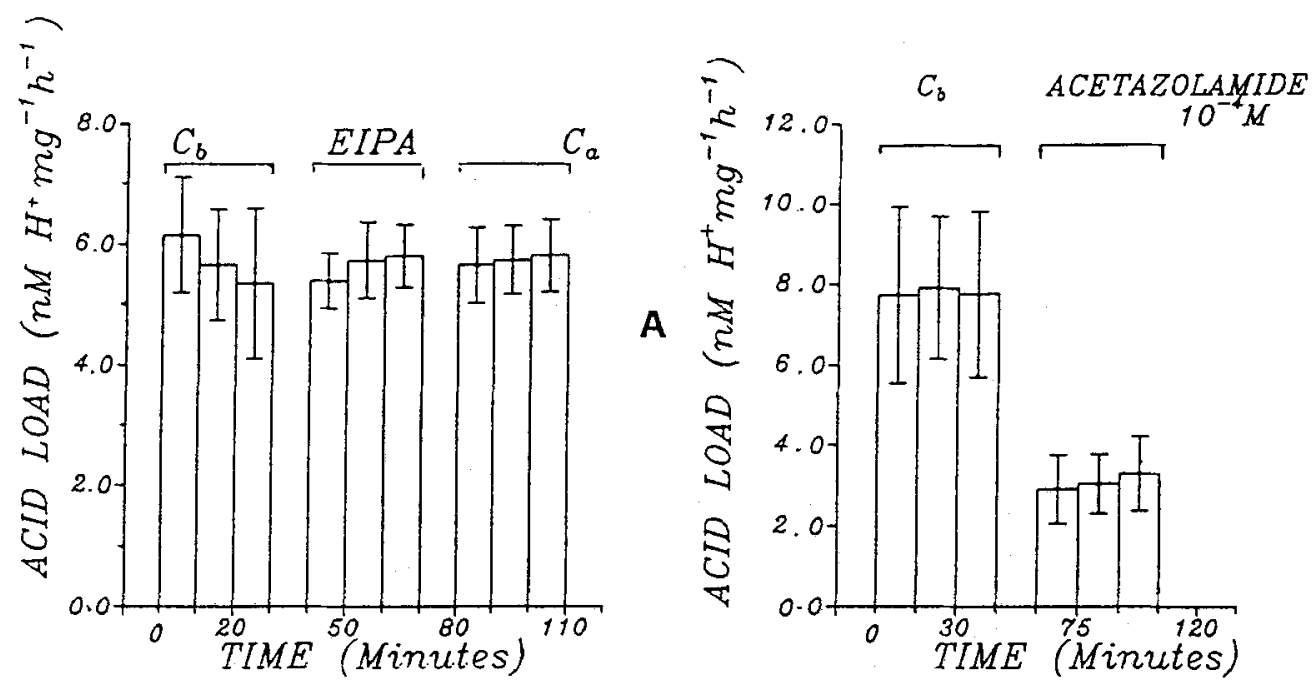

Fig. 2. Carcinus mediterraneus. Effects of 10-4 M EIPA (5-[N-ethyl-N-isopropyl]amiloride) (A) and $10^{-4} \mathrm{M}$ acetazolamide $(\mathrm{B})$ on the acid load of the DSW after perfusion of the isolated gill bathed and perfused with DSW. $\mathrm{C}_{b}$ and $\mathrm{C}_{a}=$ controls before and after application of EIPA or amiloride. Data are the means \pm s.d. of 6 experiments 
enzymatic deamination of amino acids and the degradation of nucleic acids. Also in crustaceans the most important pathway of ammonia excretion is through the gills (Cameron \& Batterton, 1976). The ammonium ion is apparently transported at the basolateral side by a carrier-mediated process. It has been suggested by Lucu et al. (1989) that ammonium ions in the hemolymph are translocated into the cell by the basolaterally located $\mathrm{Na}^{+} / \mathrm{K}^{+}$pump in which $\mathrm{NH}_{4}^{+}$appears to substitute for $\mathrm{K}^{+}$.

According to preliminary results obtained on isolated gills of the shore crab Carcinus maenas (Siebers \& Lucu, unpubl.) the presence of $\mathrm{HCO}_{3}{ }^{-}$in the medium is indispensable for extracellular $\mathrm{pH}$ regulation. It has been suggested that transport of $\mathrm{HCO}_{3}{ }^{-}$across red blood cells of fish provides $\mathrm{CO}_{2}$ (Swenson \& Maren, 1987), which can be easily transported into the cell, since the basolateral membrane of fish gills is impermeable to $\mathrm{HCO}_{3}{ }^{-}$ (Perry et al., 1982). The knowledge that $\mathrm{HCO}_{3}{ }^{-}$cannot cross the basolateral membrane of the gills has until now been frequently assumed to be valid also in crustacean gills because of their similarity to fish gills in histology and function. In the hemolymph of Carcinus and other crustaceans no CA activity has been detected, while in the gills CA activity was much higher than in any other organ and tissue tested (Böttcher et al., 1990). Future tests should focus on whether acetazolamide-sensitive acidification of the crab hemolymph described in this paper originates from increased transport of $\mathrm{HCO}_{3}{ }^{-}$from the hemolymph into the cell or by increased $\mathrm{H}^{+}$excretion from the cell into the hemolymph.

Acknowledgements. This study was supported by the Ministry of Science in Croatia, by the GermanCroatian Scientific Cooperation (financed by the Bundesministerium für Forschung und Technologie) and the Deutsche Forschungsgemeinschaft (Si 295/2-2).

\section{LITERATURE CITED}

Ahearn, G. A. \& Clay, L. P., 1989. Kinetic analysis of electrogenic $2 \mathrm{Na}^{+}-1 \mathrm{H}^{+}$antiport in crustacean hepatopancreas. - Am. J. Physiol. 257, R484-R493.

Böttcher, K., Siebers, D. \& Becker, W., 1990. Carbonic anhydrase in branchial tissues of osmoregulating shore crabs Carcinus maenas. - J. exp. Zool. 255, 251-256.

Burnett, L. E. \& Towle, D. W., 1990. Sodium ion uptake by perfused gills of blue crab Callinectes sapidus. - J. exp. Biol. 149, 293-305.

Cameron, J. M. \& Batterton, C. V.., 1976. Antennal gland function in the freshwater blue crab Callinectes sapidus. - J. comp. Physiol. 133, 219-225.

Henry, R. P., 1987. Membrane-associated carbonic anhydrase in the gills of the blue crab Callinectes sapidus. - J. exp. Zool. 245, 1-8.

Kleyman, T. R. \& Cragoe, E. J., 1988. Amiloride and its analogs as tools in the study of ion transport. J. Membrane Biol. 105, 1-21.

Krippeit-Drews, P., Drews, G. \& Graszynsky, K., 1989. Effects of ion substitution on the transepithelial potential difference of the gills of the fiddler crab Uca tangeri: evidence for a $\mathrm{H}^{+}$-pump in the apical membrane. - J. comp. Physiol. (B) 159, 43-49.

Lin, H. \& Randall, D., 1991. Evidence for the presence of an electrogenic proton pump in the trout gill epithelium. - J. exp. Biol. 161, 119-134.

Lucu, C., 1993. Ion transport in the gill epithelium of aquatic crustaced. - J. exp. Zool. 265, 378-386.

Lucu, C. \& Siebers, D., 1986. Amiloride sensitive sodium flux and potentials in perfused Carcinus gill preparation. - J. exp. Biol. 122, 25-35.

Lucu, C., Devescovi, M. \& Siebers, D., 1989. Do amiloride and ouabain affect ammonia fluxes in perfused Carcinus gill epithelium? - J. exp. Zool. 249, 1-5.

Perry, S. F., Davie, P. S., Daxboeck, C. \& Randall, D., 1982. A comparison of $\mathrm{CO}_{2}$ excretion in a 
spontaneously ventilating blood-perfused trout preparation and saline-perfused gill preparations. - J. exp. Biol. 101, 47-60.

Shetlar, R. E. \& Towle, D. W., 1989. Electrogenic sodium-proton exchange in membrane vesicles from crab (Carcinus maenas) gill. - Am. J. Physiol. 257, R924-R931.

Swenson, E. R. \& Maren, T. H., 1987. Roles of gill and red cell carbonic anhydrase in elasmobranch $\mathrm{HCO}_{3}{ }^{-}$and $\mathrm{CO}_{2}$ excretion. - Am. J. Physiol. 253, R450-R458.

Wheatly, M. G. \& Henry, R. P., 1992. Extracellular and intracellular acid-base regulation in crustaceans. - J. exp. Zool. 263, 127-142.

Wright, P. A., Randall, D. J. \& Parry, S. F., 1989. Fish gill water boundary layer, a site of linkage between carbon dioxide and ammonia excretion. - J. comp. Physiol. (B) 158, 627-635. 